\title{
Project LEAP (Leading and Engaging Activities for Parents) gateway for learners improved competencies in Araling Panlipunan
}

Aguilar, Aileen

Emilio Aguinaldo College, Philippines (aileen.aguilar@deped.gov.ph)

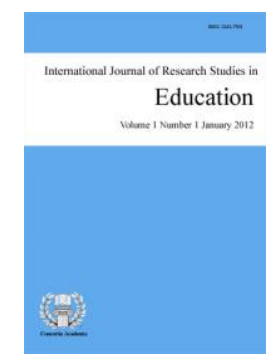

ISSN: 2243-7703 Online ISSN: 2243-7711

Received: 30 March 2021

Revised: 18 May 2021

Accepted: 30 May 2021

OPEN ACCESS

\section{Abstract}

History is really important in shaping worldwide values in the early years of life and teaching them what is right for our young people. Thus, teaching Araling Panlipunan should be a perfect example of inspiring learners into maintaining a dependable and meaningful history, including themselves and the nation. Results show that at least four main issues related to parents' and learners' challenges encountered in the Modular Distance Learning Modality, namely quality of instruction, lack of gadgets, insufficient mobile data, and parents' attitudes and learners towards the learning modality. The difficulties cited in using the modality did not greatly affect the learning competencies of learners in Araling Panlipunan because data gathered proved that learners were neither relatively nor very satisfied with what they received from the teacher and the school as well.

Keywords: Project LEAP, Araling Panlipunan, Weekly Home Learning Plan, learner competencies 


\section{Project LEAP (Leading and Engaging Activities for Parents) gateway for learners improved competencies in Araling Panlipunan}

\section{Introduction}

History is really important in shaping worldwide values in the early years of life and teaching them what is right for our young people. Thus, teaching Araling Panlipunan should be a perfect example of inspiring learners into maintaining a dependable and meaningful history, including themselves and the nation. Much as Grade 5 learners of Ananias Laico Memorial Elementary School want to embrace their love for Araling Panlipunan. In other subject areas, they were left with no choice but to utilize the Self Learning Modules (SLMs) provided by the Department of Education since the school is under Modular Distance Learning. This is a modality where there is limited even no face-to-face contact with their Araling Panlipunan teacher following the IATF rules and regulations.

Modular Distance Learning is the most commonly used modality, especially in public schools. It was a shift from a traditional method to home-based learning. True with this, parents or guardians are expected to guide and assist their children in using the SLMs. Since education is no longer held in schools, parents served as the partners of teachers in education. Parents can be learning tutors to their children and have strict rules of doing the Learning Tasks written in the Weekly Home Learning Plan (WHLP)to avoid cramming or delays in submitting Answer Sheets in school. Although modules are created for self or independent study that develop a sense of responsibility with little or less help from other people, they learned from their motivation and grew independently. Teachers create the WHLP to serve as learner's guide in answering their modules. It was modified, and the schedule for every subject area was clearly stated in it. Teachers are thinking about how learners can enjoy reading their modules and do the learning tasks so as not to feel bored, so everyday learners focus only on two subjects per day after their daily morning exercise and breakfast.

The same is true in the afternoon when there is time for them to have time for their family. These are what distance learning has to offer for the learners. Distance Learning refers to a learning modality where learning occurs between teacher and learners in a geographically remote area. Teachers have the responsibility of monitoring the progress of the learners. They may resort to having Virtual Kumustahan, Group Chat for those who have strong internet connections, phone calls and sending text messages for those learners who do not have social media accounts and internet connectivity. Although in Modular Distance learning, learners are not required to buy gadgets and force their parents to have one, some parents made way to have even basic cell phones to communicate with the teachers. The disadvantages include a challenge in the self-discipline of learners in using SLMs. Their honesty was tested for there was key to corrections at the latter portion of modules and the limited time or no time at all of the parents in assisting their children while studying at home. As cited in (https://helplineph.com/opinion/disadvantages-of-modular-learning/) when in Modular Distance learning, not all learners do their modules wholeheartedly; most learners do it for formality.

Parents also spoil their children and do the deeds of answering instead of learners and can afford to hire tutors to teach their children. And because of modern technology, learners can easily ask their classmates and copy the answers gathered instead of thinking of the correct answers. Another is that learners kept on saying they did not understand what the modules were. When in school, they even have difficulty understanding the lesson during face-to-face instruction. It is more difficult when even parents cannot understand the modules. The key purpose of this research is to find out the challenges encountered by parents and learners directly from their tongue in studying Araling Panlipunan, its effects on the competencies of the learners. Furthermore, this helped to know which engagement activities are best suited for parents to improve the learning competency of learners and find out the difference between learners who are simply using modules in learning the subject against those who have internet access. 
According to D. Gross (2020), parent engagement in early learning has historically been broadly defined. It is unclear whether those designing, implementing, evaluating, or participating in parent engagement initiatives conceptualize parent engagement in the same way. Lack of consensus could contribute to the poor quality of parent-school partnerships and reliance on parent engagement measures and strategies that lack meaning and utility. This is true because whatever programs or activities the school and the teachers offer to parents for their children won't accept it wholeheartedly. It would be just like a waste thrown in a basket. In this manner, this research tried to reach out to parents and for teachers, school and parents together with the learners to have a harmonious learning environment and relationships.

\subsection{Significance of the study}

It was long being declared the importance of parental involvement in the academic progress of children. Families contribute to the child's socio-emotional and cognitive development. Findings have demonstrated a positive association in improving the child's esteem and their academic performance. Garbacz et al. (2017) noted that not all children are privileged to have parents who are always on time to study their lessons. Still, blessed are supportive parents who stayed beside them, especially in answering their modules. The same is true with those who have strong internet connectivity. They have chances to build communications with their teachers online. The Internet plays a major role in the lives of young people today.

Children and youngsters engage in online activities both inside and outside the classroom (Sefton-Green 2004). Formally, in school, young people use the Internet to search for information and complete tests. Moreover, they can research to help them answer their modules, unlike those who were ought to use the copy of modules. In other words, they have limited resources. This study is significant to the learners and parents because through Project LEAP, there is constant communication between the teacher, parents, and the learners through Virtual Kumustahan, chat messages, phone calls, and sending text messages. The teacher also benefited from this because he/she will be updated on the developments of the learners while studying at home. This is also an advantage to learners using modules for teachers using phone calls and even text messaging to reach them and their parents.

The teacher provided further learnings and guidance because they can give fact sheets or additional information and even provide them with self-made video lessons. This implies that teachers should know how to utilize their videos and those of other teachers to improve their instructional skills and the learning of their students. These initiatives have also urged teacher educators to prepare and use video-recorded instruction in classrooms or field-based practices (Arya \& Christ, 2013). There is an additional source of information that parents and learners can get from the teacher and will surely help learners understand the lesson. Furthermore, because of constant communication, parents are engaged in improving the competency of their children, for they will be provided with additional learning by the teacher through fact sheets given to them. Thus, it will be beneficial to the learners and parents deprived of education in their early years. Thus, hitting two birds in one stone.

The study's findings based on the collection methods were synthesized and answered. Guided by TOJDE (2004), the study tackled three types of interactions: learner-content interaction, learner-instructor interaction, and learner-learner interaction. The study focused more on learner-content interaction and learner-instructor interaction. The relevance of communication between the two, as cited by Taylor (2006), is that distance learning is a field of education that focuses on using technology in delivering curriculum to students. Students who are not physically on-site receive their education and are supported by (Singh, 2003). Teaching and learning at a distance can be delivered via full electronic learning, otherwise known as single delivery mode programs (synchronous or asynchronous) or blended delivery mode programs. The teacher's constant communication with the parents would contribute to a meaningful teaching-learning situation even if learners are at their homes. 


\section{Methodology}

This action research was undertaken at Ananias Laico Memorial Elementary School, the researcher's place of the station, in the district of Magdalena province of Laguna, from October 2020 to March 2021, the end of the 2nd quarter. This action research focused on the improved competencies of Grade 5- Mabini learners in Araling Panlipunan since the researcher is an Araling Panlipunan teacher. The data on improved competency of Grade 5Mabini learners will use the experimental method to show learners who do not have access to the Internet against strong internet connections under Project LEAP and descriptive qualitative approach. Data were collected from 42 parents falling in the inclusion criteria. Considering the lockdown problem, the data were collected via Google docs form with open-ended questions related to COVID-19 and home learning, also used phone calls and text messaging. Data collected were collated at the end of the research study. Mean, percentage and rank were used to treat the data gathered.

\section{Findings and discussions}

The study's findings from the two data collection methods, which are presented, in the methodology section, were synthesized into four categories, namely challenges encountered by parents and learners in-home -learning. The second is an effect on the learning competency of learners in Araling Panlipunan. The third is the best engaging activities that serve as a gateway to parents' help improve the learning competency of their children at home. The fourth one is the significant difference between learners using modules only compared to those with internet connectivity in studying Araling Panlipunan.

\subsection{What difficulties in Modular Distance Learning?}

Advantages have been divulged in using Modular Distance Learning Modality, but some factors remain unsolved and need to be addressed. These problems include the (i) quality of instruction, (ii)lack of gadgets, (iii)insufficient mobile data, and (iv) the attitudes of students and parents towards modular distance learning. Each one of these affects the overall learning competency in the subject area, which is Araling Panlipunan. In many ways, each of these issues relates to the others. Therefore, we will examine each of these issues separately.

Quality of instruction - The first issue is the quality of instruction that is given through distance learning programs. Recent trends in teachers' professional development stem from an increased understanding of the importance of the teacher's role, which influences the learners, improves their competencies in learning. In addition, teachers are the most important factor in their students' achievements (Gerard, Varma, Corliss, \& Linn, 2011.) Therefore, the teacher takes the responsibility of monitoring the progress of the learners. If possible, they will conduct home visits to check on each student's progress and performance.

Lack of gadgets - Initial data from the enrollment survey conducted by the Department of Education (DepEd) showed a significant number of parents citing the lack of gadgets, insufficient mobile data allowance, and an unstable internet connection, the three issues are among the primary challenges that they believe may affect their children's learning process. More than 6.9 million cited unstable mobile and internet connections, while over 6.8 million noted a lack of available gadgets and equipment suitable for distance learning. Although gadgets were not necessary for Modular Distance Learning, learners and parents need to have either one basic phone to communicate with their children's teachers.

Insufficient mobile data - Based on the survey conducted on 42 parents, 49 percent had network signals but did not have internet connections in their households, while 51 percent lacked both. The increase in internet usage reflects new information technology as the world of communication technology that can improve learning. The Internet is also very important for people's everyday lives nowadays. Globalization creates opportunities and challenges for learners in higher education to emphasize information and communication technologies (ICTs) such as internet usages (Macharia \& Nyakwende, 2011). But this issue is hard on the part of the researcher to sustain. There is a proper authority to solve the issue, but it is undeniable that mobile data is not needed in this 
technologically evolving world. The investigation of the relationship between internet usage and learning is useful to ensure that the learning improvement needs to emphasize internet usage and motivate students to use the Internet in their learning. According to Sylvia (2000), internet usage in education can help with individual learning and teaching, such as quickness of delivery, development of communication and writing skills, and increased motivation for learning and self-reliance.

\subsection{Attitudes of parents and learners toward distance learning}

Distance learning has many positive assets. Firstly, students are provided with the flexibility to learn at their place (Thoms \& Eryilmaz, 2014). Moreover, various educational tasks enable learners to adapt their learning schedule according to their learning style without following a structured tactical schedule of learning. In this way, distance learning programs provide the flexibility for students to decide on their course of learning, as students can participate in the learning process from their homes (Davis et al., 2019). Additionally, for those who want to improve their professional and academic qualifications without leaving their jobs, distance education is often beneficial, as distance learning can serve both learning and working (de Oliveira et al., 2018).

Distance learning involves individualized instruction that allows learners to use self-learning modules (SLMs) in print or digital format/electronic copy, whichever is applicable in the context of the learner, and other learning resources like Learner's Materials, textbooks, activity sheets, study guides, and other study materials. Learners access electronic copies of learning materials on a computer, tablet PC, or smartphone. CDs, DVDs, USB storage, and computer-based applications can all be used to deliver e-learning materials, including offline E-books. The teacher takes the responsibility of monitoring the progress of the learners. The learners may ask assistance from the teacher via e-mail, telephone, text message/instant messaging, etc. Where possible, the teacher shall do home visits to learners needing remediation or assistance. Any family member or other stakeholder in the community needs to serve as a para-teachers or as if a teacher. From the interview conducted by the teacher, $65 \%$ of parents of learners preferred face-to-face instruction because, for them, it is very difficult to teach the subjects to their children due to their lack of knowledge about the competencies. However, there was the information written in the beginning of every module. Based on the data gathered, the teacher regarded the $65 \%$ of parents need engagement activities to support the home study of their children fully.

\subsection{How do these difficulties affect the learning competency of learners in Araling Panlipunan?}

Despite the challenges encountered in distance learning, $65 \%$ of learners were relatively satisfied with their receiving. In addition, 35\% of Grade 5-Mabini learners of ALMES were very satisfied because they can communicate well with the teacher by using technology.

$>\quad$ Which engagement activities will serve as a gateway to engage parents and improve learner's competency in Araling Panlipunan 5 in Modular Distance Modality?

Table 1

Activities that serve as a gateway to engage parents in learner's competency in Araling Panlipunan

\begin{tabular}{|c|c|c|c|}
\hline Engagement Activities & $\begin{array}{l}\text { No. of Responses } \\
\text { (Parents/Guardians) }\end{array}$ & Percent & Rank \\
\hline Virtual Kumustahan & 4 & 10 & 2 \\
\hline Group Chat (GC) & 34 & 81 & 1 \\
\hline Phone Call & 1 & 2 & 4 \\
\hline Sending Text Messages & 3 & 7 & 3 \\
\hline Total & 42 & 100 & \\
\hline
\end{tabular}

As shown on the table, $81 \%$ or 34 parents preferred Group Chat (GC) as a very engaging activity. At the same time, Virtual Kumustahan ranked 2 in the list, followed by sending text messages with three-parent responses or $3 \%$, and lastly is phone call as the last option of parents with only one response or $2 \%$ of the 
Aguilar, A.

participants.

$>$ Is there a significant difference between learners using modules only in studying Araling Panlipunan 5 against learners with internet connectivity intervention in their studies?

The computed $p$-value 5.46956 is high or (Greater than 0.05 ). Therefore, the probability that the observed results are due to random chance is high. This will be the case if the calculated t-value is below the t-critical value. So, based on the result, it was concluded that Ho or There is no significant difference between learners who are using modules only compared to those in Modular Distance learning but with internet connectivity at home.

\section{Conclusion}

Based on the above research findings, at least four main issues related to parents' and learners' challenges encountered in the Modular Distance Learning Modality, namely quality of instruction, lack of gadgets, insufficient mobile data, and parents' attitudes and learners towards the learning modality. The difficulties cited in using the modality did not greatly affect the learning competencies of learners in Araling Panlipunan because data gathered proved that learners were neither relatively nor very satisfied with what they received from the teacher and the school as well. The $65 \%$ of parents preferred Group Chat (GC) as the best engaging activity for them to help teachers and schools improve the learning competency of their children in the subject Araling Panlipunan. It showed that they longed for constant communication and activities that the teacher and school would give them to be used at home to be engaged more in the success of the learning of their children. Furthermore, it was proven that there is no significant difference either learners are simply using modules alone than those who have internet connectivity intervention in the Modular Distance Learning Modality.

In this respect, to address the concern of parents and learners, teacher and school head worked collaboratively to address the gap in the teaching-learning instruction by providing teacher self-made video lesson that can be shared to the Group Chat (GC) of parents and so they can also share and watched it together with learners as well as those who do not have gadgets at home. In this manner, parents and learners are engaged in the activity as they also learned together. Furthermore, the teacher prepared Fact sheets and Learners Activity Sheets for those parents and learners who are not privileged to acquire even basic cell phones to be distributed during retrieval day as allowed by the IATF. This research can offer to parents and the most important client of school- the learners. Education must continue in this time of the pandemic, as stated by DepEd Secretary Leonor Magtolis -Briones. Learning will not necessarily mean traditional face-to-face learning in the classroom. In this time of the pandemic, different learning modalities were offered by the Department of Education. The physical opening will depend on the risk severity grading or classification of a certain community according to guidelines from the Department of Health (DOH), the Inter-Agency Task Force (IATF) for the Management of Emerging Infectious Diseases in the Philippines, and the Office of the President (OP). Meanwhile, the researcher wished for parents and learners to deeply embrace everything that the school and teacher can offer in the meantime.

\footnotetext{
Acknowledgments - The author wishes to acknowledge her School Head in the person of Maam Severa C. Versola. Furthermore, to the Education Supervisor in Araling Panlipunan, Dr. Lucy F. Pagalanan, for the unselfish support to the researcher in the whole time of the conduct of research, also to the Dean of Graduate Studies of Emilio Aguinaldo College, Manila Dr. Lino Reynoso for the encouragement he gave to his students, to Emilio Aguinaldo College where the researcher was exposed more to dissertation writings, and a refresher course offered that helped the researcher understand more about research, to the researchers family her husband Jay and daughters Jayleen, Yajeen and Leiane Jay, most importantly to the Lord above who gave enough wisdom and strength to the researcher and believed that she could produce one. Lastly, the author wishes to declare that there is no conflict of interest in the publication of this article.
} 


\section{References}

Bernardo, J. (2020). Modular learning most preferred parents. DepEd. ABS-CBN News.

FlipScience. (2020). Tagapagdaloy: How Filipino parents can help ensure. Retrieved from http://www.irrodl.org/index.php/irrodl/article/view/3672/4730

https://en.wikipedia.org/wiki/COVID-19_pandemic

https://files.eric.ed.gov/fulltext/ED494550.pdf

https://helplineph.com/opinion/disadvantages-of-modular-learning/

https://news.abs-cbn.com/news/07/30/20/modular-learning-most-preferred-by-parentsdeped

https://www.researchgate.net/publication/341981898_The_COVID19_Pandemic_through_the_Lens_of

https://www.teacherph.com/deped-learning-delivery-modalities/

https://www.westga.edu/ distance/ojdla/fall53/valentine53.html

Inquisitive Filipino. https://www.flipscience.ph/news/features-news/tagapagdaloymodular-distance learning/

Lego, M. A. (n.d). DepEd learning delivery modalities for school year 2020-2021. teacher. Modular distance learning. FlipScience - Top Philippine Science News and Features

Nardo, M. T. B. (2017). Modular instruction enhances learner autonomy.

Philippine Information Agency. https://pia.gov.ph/news/articles/1046619

Quinones, M. T. (2020). DepEd clarifies blended distance learning modalities for SY 2020-2021. Retrieved from https://www.teacherph.com/deped-learning-delivery-modalities

Tria, J. Z. (2020). The COVID-19 pandemic through the lens of education. 
Aguilar, A. 